\title{
Pilosopiyang Pinoy: Uso Pa Ba? (The Relevance of Filipino Philosophy in Social Renewal) ${ }^{1}$
}

Romualdo E. Abuladt

\begin{abstract}
This paper evaluates the titular question and features a summative evaluation and critique of the works and contributions of Leonardo Mercado, Dionisio Miranda, Albert Alejo, Rolando Gripaldo (1947-2017), and Florentino Timbreza to the anthropological and cultural approaches that form a significant part of the discourses on Filipino philosophy. In this piece, Abulad maintains, as in his other writings, that any strict emphasis with regard to methodology restricts the true potential of Filipino philosophy. He buttresses this assertion by invoking postmodernism's 'incredulity towards metanarratives' We should be skeptical about the metanarrative of Filipino identity for it is precisely our rootlessness that defines us. Towards the end, he cites Emerita Quito's openness as a distinct philosophical attitude that had made her, to-date, unsurpassable. This remarkable trait, for Abulad, should inspire us to welcome the new: with the "collapse of borders and the merger of horizons," it would serve us well to continuously rethink the role of philosophy.
\end{abstract}

Keywords: Filipino philosophy, anthropological approach, cultural approach, postmodernity

W hen I accepted your invitation for me to speak at your annual Regional Philosophy Gathering, what attracted me mainly was the intriguing theme of your celebration: "Pilosopiyang Pinoy: Uso pa ba?" Uso pa ba ang Pilosopiyang Pinoy? Actually, my suspicion is what you'd like to ask is really a more general question: Uso pa ba ang Pilosopiya? The specific reference to Filipino Philosophy makes the situation even worse.

${ }^{1}$ Editor's note: An early version of this piece was presented in the $10^{\text {th }}$ Philosophical Conference of the Sancta Maria Mater et Regina Seminarium, Archdiocese of Capiz, Roxas City, 18-20 November 2010. We would like to thank Preciosa de Joya of the Department of Philosophy, Ateneo de Manila University, for graciously supplying us with an early copy of the manuscript.

(c) 2019 Romualdo E. Abulad

https://www.kritike.org/journal/issue 25/abulad1 december2019.pdf

ISSN 1908-7330

(cc) BY-NC-ND 
Its implication is that there is such a thing as "pilosopiyang Pinoy," and the question being asked is only whether it is still relevant: uso pa ba? But the assumption is itself a question deserving to be asked: Mayroon bang Pilosopiyang Pinoy? Ano ba ito? Only after having satisfied this latter question (Ano ba ang Pilosopiyang Pinoy?) will it be meaningful to ask about its relevance, if at all. In a philosophical discussion, we might as well not assume anything, or else we might find ourselves deeply in trouble later.

And so, let me begin by asking the assumed question: Is there a Filipino philosophy? And the proof for a positive answer to it can only be found in the actual articulation of it. Without this articulation, it will be difficult even to show that there is such a thing as a Filipino philosophy. Maybe, in the first place, we are talking about nothing. At this point, indeed, it would be better not to assume anything and so we need to ask: Is there a Filipino philosophy?

We need to give credit to whom it is due, and we must yield to Leonardo Mercado the right to claim to have consciously written the first book on Filipino Philosophy. His Elements of Filipino Philosophy (1974), though not impeccable, is a landmark work. What he says in the Preface is not inaccurate: "This pioneering work is the first systematic attempt to present the philosophy of the Filipino masses." 2 This doesn't mean that Mercado is the first Filipino philosopher, only that he is the first Filipino philosopher to have tried to present a systematic philosophy which he conceived to be a 'philosophy of the Filipino masses.' There are two things to notice here: first is that Mercado claims to have presented a 'systematic philosophy' and second is that this philosophy is that of the 'Filipino masses' or the 'common tao.' He justifies this claim by stating that his method involves "an analysis of Philippine languages" and "a phenomenology of Filipino behavior." $\mathrm{He}$ further elucidates this in Chapter I where he describes as 'holistic' his methodology ${ }^{3}$ which consists of 'metalinguistic analysis' and 'phenomenology of behavior,' neither of which is, to be frank, indigenously Filipino. In a previous work, I described this method of Mercado as 'anthropological,' ${ }^{4}$ and it is no accident that among the prominent authors mentioned here are Claude Levi-Strauss and Emile Durkheim, ${ }^{5}$ as well Benjamin Lee Whorf and Edward Sapir. ${ }^{6}$ As to phenomenology, the ones

\footnotetext{
2 See Leonardo N. Mercado, Preface to Elements of Filipino Philosophy (Tacloban City: Divine Word University Publications, 1993).

${ }^{3}$ Ibid., 8.

${ }^{4}$ In the textbook I prepared for the Philosophy Department of the De La Salle, I mentioned in the Introduction three philosophical options for a Filipino philosophy: expository, anthropological, and progressive. See Readings in Filipino Philosophy (Manila: De La Salle University, 1990), 4 passim.

${ }^{5}$ Mercado, Elements of Filipino Philosophy, 12.

${ }^{6}$ Ibid., $42-43$.
}

(C) 2019 Romualdo E. Abulad

https://www.kritike.org/journal/issue 25/abulad1 december2019.pdf

ISSN 1908-7330 


\section{PILOSOPIYANG PINOY}

featured most are Husserl, Heidegger, Sartre and Merleau-Ponty, ${ }^{7}$ without excluding the other philosophers of language such as Ludwig Wittgenstein I and $\mathrm{II}^{8}$ and the analytic philosophers. This makes phenomenology and analysis rather apt descriptions of his method which, however, cannot really qualify as something indigenously Filipino. The anthropological approach, after all, is universally accepted, and my suggestion is that it cannot be this which makes Mercado's philosophy Filipino. It is also a question when an anthropologist, not a philosopher, could have been the more qualified expert to undertake this.

If not the anthropological approach, what makes Mercado a uniquely Filipino philosopher? Perhaps the answer has to do with the object of his studies, namely, Filipino languages and Filipino behavior. A prominent feature of his work is the tables of intellectual, volitional, emotional and ethical themes comparing the Visayan, Tagalog, Ilocano and the English languages in their use of the concept of "loob/buot/nakem." 9 This would have been an impressive contribution to both philosophy and anthropology if the scope of this magnitude were given by the author the thorough treatment that it deserves. The chapters not only on loob/buot/nakem but also on the verbs, kinship, time, space, causality, private property, law, and religion were too brief to be credibly anthropologically exhaustive. In the end, the reader has to be satisfied with the following conclusion, that, negatively, the Filipino's worldview is "non-dualistic," "non-compartment-alized," and "nonlinear." 10 None of these concepts is original, for they describe as well the other Oriental philosophies which go for man's natural harmony and goodness. ${ }^{11}$ If this is the philosophy of the 'common tao,' then that 'common tao' must be Chinese and Indian as well. The picture that emerges at the end of his study is the stereotype of an Oriental and one is left to wonder if this stereotype did not in fact came ahead of his investigation and methodology.

I am not sure I know of a solid disciple of Mercado who actually swears by everything he does methodologically and philosophically. His latest work, Explorations in Filipino Philosophy, ${ }^{12}$ is a worthy companion but does not exceed the first work, Elements of Filipino Philosophy-the latter remains as his most important work. The multi-volume that would have made the opus of Mercado classic and immortal had not materialized, and the actual work is perhaps better done by anthropologists than by

\footnotetext{
${ }^{7}$ Ibid., 11 , also $18-27$.

8 Ibid., 27-40.

${ }^{9}$ Ibid., 55-64.

${ }^{10}$ Ibid., 191-192.

${ }^{11}$ Ibid., 193 (on the orientality of Filipino philosophy).

${ }^{12}$ Leonardo N. Mercado, Explorations in Filipino Philosophy (Manila: Logos Publications,
}

2009).

(c) 2019 Romualdo E. Abulad

https://www.kritike.org/journal/issue 25/abulad1 december2019.pdf

ISSN 1908-7330

(c) $)$ BY-NC-ND 
philosophers. This does not mean, however, that the anthropological approach has no adherents among Filipino philosophers; indeed, Mercado remains the pioneer in this work for which he will be remembered. Let me now randomly go through some of our philosophers who, consciously or not, are using the method of anthropology.

I would like to give attention to another philosopher who, like Mercado, is a Catholic missionary. They are both my confreres, ${ }^{13}$ but that's not the reason why I am here singling them out. The reason is rather that they have both done remarkably well in the field of scholarship which they have chosen to take part in. There is no doubt that, of the two, Dionisio Miranda is the more thorough and exhaustive writer, perhaps also the more articulate and original one. He makes no bones about his engagement with culture which he defines "in its most generic meaning as the conceptualizing of reality and responding to the same which persons learn as members of a social group." 14 Unlike Mercado, Miranda admits his "limited experience"15 in the area of inculturation, which makes even more for the credibility of his project. "My own proposal for methodical inculturation in the area of philosophical and theological inculturation," he declares, "consists basically of a two-pronged approach to the culture issue. Those prongs are indigenization and contextualization." 16

This makes Miranda's approach concrete and, despite his academic eloquence, never merely an armchair and ivory-tower intellectual exercise. He stays consistently on the level of his own understanding of inculturation, that it "cannot prescind from a discussion of concrete society that must ultimately undertake it. Inculturation is ultimately a discourse about society itself." ${ }^{17}$ Interestingly, he considers it "imperative for inculturation to be selfconscious and critical of itself and its own projects." 18 And, in the case of the Philippines, he contends that "authentic inculturation cannot ignore the majority poor as its chief responsibility and resource." 19 Thus, Miranda wisely avers that inculturation "is not an abstract idea; it is a practical process that occurs in the concrete." ${ }^{20}$ He situates his interest unambiguously in Filipino

${ }^{13}$ Editor's note: Abulad, Mercado, and Miranda are members of the Societas Verbi Divini (SVD).

${ }^{14}$ Dionisio M. Miranda, Buting Pinoy: Probe Essays on Value as Filipino (Manila: Divine Word Publications, 1992), 6. However, the biographical note on the back cover of the book says that he has been on the council of the SVD Philippine Central Province since 1987. The book must have been written, then, after that year, more than a decade after Mercado's Elements was first printed.

${ }^{15}$ Ibid., 10.

${ }^{16} \mathrm{Ibid}$.

${ }^{17}$ Ibid., 15.

${ }^{18}$ Ibid.

${ }^{19}$ Ibid., 16.

${ }^{20}$ Ibid., 19.

(C) 2019 Romualdo E. Abulad https://www.kritike.org/journal/issue 25/abulad1 december2019.pdf ISSN 1908-7330 


\section{PILOSOPIYANG PINOY}

culture with a particular professional focus on "the specific cultural processes and interactions ... that bear on the field of ethics in both the philosophical and theological variants." 21 Still, he defines his area of engagement within "fundamental and/or general moral theology" and argues that there will always be a need too for theoreticians with long-term commitment "who will appear to have little immediate relevance." 22

Where Miranda comes close, albeit unconsciously, to Mercado can be gleaned from the spirit of the following text:

Culture, especially the indigenous, is as intimate as skin; it is not like a vestment that can be casually disrobed ... But there is a change that is possible and desirable: it is to recover the original self and reshape it in more authentic ways. That is radicality in its true sense: to return to the roots of being and existence, to recover the originality of culture and the creativity of history. ${ }^{23}$

One can sense the same missionary zeal in the preoccupation of both philosophers of the Filipino culture, but Miranda is the one more clearly aware of the radicality of even a proposed Filipino theory which "is not to be merely one more conception whose only value lies in its local color or folkloristic aspects." 24

In this small essay I cannot even attempt to cover the whole intent of Miranda's ambitious project. Enough to say that his inquiry attempts to cover socio-cultural data as the source of his notion of value. For him the philosophical question is: "what is implied in the notion of value culled from the social-cultural data?" 25 Interestingly, again sounding altogether like Mercado, he describes the first step of his approach to the philosophy of culture as "that of phenomenological description" whose task is "to delineate the basic constituent elements of Filipino morality." 26 This "phenomenological analysis" is then followed by "constructive analysis" on the ethos level and the "critical analysis" on the ethics level. ${ }^{27}$ Somewhat like Mercado, he goes linguistic in what he calls the "search for a Tagalog name" for the English 'value,' thus describing his approach as "terminological-

\footnotetext{
${ }^{21}$ Ibid.

22 Ibid., 20.

${ }^{23}$ Ibid., 22.

${ }^{24}$ Ibid., 23.

${ }^{25}$ Ibid., 36.

${ }^{26}$ Ibid., 37.

${ }^{27}$ Ibid., 37-39.
}

(c) 2019 Romualdo E. Abulad

https://www.kritike.org/journal/issue 25/abulad1 december2019.pdf

ISSN 1908-7330

(c) $)$ BY-NC-ND 
conceptual" and "conceptual-terminological" to be completed in a more "dialectical approach" that eventually arrives at "buting Pinoy." 28

Loob is a favorite concept of investigation among those who use the anthropological approach, granting of course its variants. ${ }^{29}$ One book exclusively written on it is Albert E. Alejo's Tao pô! Tulóy!, subtitled Isang Landas ng Pag-unawa sa Loob ng Tao. ${ }^{30}$ Written wholly in Tagalog, one of its revealing features is the chapter where he presents various writers on loob, which includes philosophers like Leonardo Mercado and Roque Ferriols, but mostly historians like Emmanuel Lacaba, Zeus Salazar, Reynaldo Ileto, and Vicente Rafael. ${ }^{31}$ Alejo explains his title: "Ang unang bahagi ay tinaguriang 'TAO PO!' dahil para tayong naghahanap ng landas patungo sa loob ... Sa ikalawang bahagi, tila pinapayagan tayong makapasok sa loob kaya nga ang salubong sa atin ay 'TULOY!'”32 My surmise is he initially hopes to be able to complete the description of the Filipino loob, inside and out, and thus coming up finally with a definitive account of the Filipino identity. In the end, Alejo knows he succeeds in doing something less than that. "Wala akong nalikhang depinisyon." 33 He adds, "Hindi ito, kung sa bagay, ang aking intensyon." There seems to be a sense of frustration here, buoyed up only by his promise to himself that there are more works to come. "Kaya't sa aking pananaw, ang paglitaw ng sanaysay na ito ay isa lamang pasinaya sa marami pang darating." 34 It doesn't seem like this promise has been fulfilled, nor is this fact something we should deplore. I would rather take this seeming failure of Alejo's enterprise as precisely an essential part of his main contribution to Filipino philosophy, so that it becomes something which no one needs to undertake again. Perhaps without his being conscious of it, he is actually only repeating, albeit in an indigenous way, what even in the West spells a dead-end.

The loob is not really a Filipino discovery. It is equivalent to the Socratic self, as in "Know thyself!" 35 It is the Greek psyche, Aristotle's anima or soul which is the inner essence or form, the counterpart

${ }^{28}$ Ibid., 48-59.

${ }^{29}$ For Mercado's discussion of "loob," see Elements of Filipino Philosophy, 53-71; also, The Filipino Mind: Philippine Philosophical Studies II (Manila: The Council for Research in Values and Philosophy and Divine Word Publications, 1994), 19-37. For Miranda, see Buting Pinoy, 124130 .

${ }^{30}$ Albert E. Alejo, Tao pô! Tuloy! Isang Landas ng Pag-unawa sa Loob ng Tao (Quezon City: Ateneo de Manila University Office of Research and Publications, 1990).

${ }^{31}$ See ibid., Chapter 2.

${ }^{32}$ Ibid., ix.

${ }^{33} \mathrm{Ibid} ., 117$.

${ }^{34}$ Ibid., 116.

35 Plato, Phaedrus, trans. by R. Hackforth, in Plato: The Collected Dialogues, ed. by Edith Hamilton and Huntington Cairns (New Jersey: Princeton University Press, 1973), 230a.

(C) 2019 Romualdo E. Abulad https://www.kritike.org/journal/issue 25/abulad1 december2019.pdf ISSN 1908-7330 


\section{PILOSOPIYANG PINOY}

of the external body or matter. ${ }^{36}$ This is also the Geist of German Idealism culminating in the Absolute Spirit after its long and laborious journey which Hegel calls its phenomenology. ${ }^{37}$ One might say that Hegel is more successful than Alejo in that at least the former was able to construct what could be described as the greatest system ever conceived by the Mind. However, we all know that this Absolute of Hegel is precisely the model for the metanarrative which later philosophers would love to explode and deconstruct. ${ }^{38}$ Moreover, the fact that Alejo discovers in the end the emptiness of the loob he wants to explore is most likely indicative of his captivity, perhaps unconscious, in the dualism normally attributed to Western philosophy between external and internal, object and subject, contents and thoughts. We're here back to the Cartesian tension between mind and body, of course with a flavor that is Alejo's own.

One should not take this critique of Alejo as pejorative. That I compare his achievement to such greats as Socrates, Descartes and Hegel is enough to prove that I don't mean to hurt anyone's philosophical project. Philosophy, like any other academic discipline, thrives on the criticisms of those within the circle of our profession. We challenge each other until we are able to see the light of day for the work we wish to leave behind.

Another Filipino philosopher whom I would count, along with Mercado, Miranda and even Alejo, as mainly anthropological is Rolando Gripaldo. This is not to mean that they are doing exactly the same work. Gripaldo will revolt against any insinuation to that effect; he would cringe at the thought of being placed side by side with, say, Mercado and Timbreza. He admits that a "cultural rethinking of Filipino philosophy is important, but it should be a philosophical reflection of our existing culture as a whole or of our individual cultural traits." 39 This is the sense in which we take him to fall under our anthropological label; I don't mean much more. He would rather take the meaning of Filipino philosophy, with his own presumably as an example, as something profound and substantial. "The important thing in philosophizing," he says, "is not simply tangential philosophical reflections

${ }^{36}$ Aristotle's theory of hylemorphism is found in De Anima, trans. J.A. Smith, in The Basic Works of Aristotle, ed. by Richard McKeon (New York: Random House, 1941), 412b10-13.

37 Hegel describes the phenomenology of mind or the "gradual development of knowing' as a "long and laborious journey (that) must be undertaken." See G.W.F. Hegel, Phenomenology of Mind, trans. by J.B. Baillie (New York: Harper \& Row, 1967), 88.

${ }^{38}$ See Jean-Francoiş Lyotard's postmodern critique of metanarratives in The Postmodern Condition: A Report on Knowledge, trans. by Beoff Bennington and Brian Massumi (Minneapolis: University of Minnesota Press, 1993). See also Jacques Derrida's famous theory of deconstructionism, for instance in Margins of Philosophy, trans. by Alan Blass (Brighton, Sussex: The Harvester Press, 1982).

39 Rolando M. Gripaldo, The Making of a Filipino Philosopher and Other Essays (Mandaluyong City: National Book Store, 2009), 70.

(c) 2019 Romualdo E. Abulad

https://www.kritike.org/journal/issue 25/abulad1 december2019.pdf

ISSN 1908-7330

(cc) BY-NC-ND 
but substantial philosophical innovativeness that could have ramifications in the philosophical world." 40 "What we need are philosophical innovations that are distinctively the product of profound philosophical minds, something that will separate one's thoughts from the thoughts of others before him or her," Gripaldo continues, "and I think this is one of the great challenges of a would-be Filipino philosopher." 41 He thinks that we need already "to graduate from (the) kind of piecemeal analysis" which our country's thinkers are wont to indulge in.

Gripaldo justifies his own philosophical training. "My background in Western philosophy and my studies in Oriental philosophy were enough training and material to know what to look for in the writings of Filipino thinkers," is how he judges himself. "Moreover," he says, "a good working background on Western and Eastern thought is also generally important in becoming a world-class philosopher." 42 "Do I have a philosophy of my own?," he asks. "The answer is affirmative," and he dares to answer his own question, admitting simultaneously however that "I have not yet written it in one book." He continues to promise, "in due time, I intend to write a volume or two about my own comprehensive systematic philosophy. After all, our task is to make ourselves philosophers, not just teachers or scholars of philosophy." 43 When I read this, I could not help being reminded of another great teacher, Confucius, who said something opposite to what has just been said by Gripaldo: "I transmit but do not create. I believe in and love the ancients." 44 "A man who reviews the old so as to find out the new is qualified to teach others." 45

Gripaldo dreams "to situate Filipino philosophy in world history" 46 and sadly takes note that our making a dint in world philosophy circles "is virtually zero." 47 "In the World Congress on Mulla Sadra held in Tehran in 1999, I was the only Filipino there who read a paper on the theory of speech acts," Gripaldo laments, "I was the only Filipino who presented a paper in the American Philosophical Association Conference held in December 2006 in Washington, D.C." ${ }^{48}$ One wonders whether it was his trip beyond Greece which made Plato such a great philosopher.

\footnotetext{
${ }^{40}$ Ibid., 60.

${ }^{41}$ Ibid., 70.

42 Ibid., 73.

${ }^{43}$ Ibid.

${ }^{44}$ Confucius, The Analects, trans. by Wing-tsit Chan, in A Source Book in Chinese Philosophy (Princeton, New Jersey: Princeton University Press), 7:1.

${ }^{45}$ Ibid., 2:11.

${ }^{46}$ Gripaldo, The Making of a Filipino Philosopher and Other Essays, 73.

${ }^{47}$ Ibid., 74.

${ }^{48}$ Ibid.
}

(C) 2019 Romualdo E. Abulad https://www.kritike.org/journal/issue 25/abulad1 december2019.pdf

ISSN 1908-7330 


\section{PILOSOPIYANG PINOY}

Perhaps still the best work of Gripaldo is his early work, Circumstantialism (1977). ${ }^{49}$ But this little work has for its thesis clearly articulated already on its first page, and the rest of the booklet says nothing much more.

What will be demonstrated in this essay is the thesis that the alleged free choice is not free at all in that there are always some subtle influencing factors or reasons which determine, in the sense of giving direction or tendency to, the choice ... of the individual such that this choice stands out as the only alternative fitting or appropriate in that situation. ${ }^{50}$

This variant of the philosophy of determinism is what Gripaldo calls "situational determinism" or, as the title of his booklet calls it, "circumstantialism." It is "something like a hybrid between the ethical and the psychological types of determinism." ${ }^{51}$ "It is by virtue of the complex reasons for the choosing act that the best in the situation relative to the agent's values or purposes is laid bare." 52 There is certainly nothing yet here which can pass the requirements Gripaldo lays down for a great Filipino philosophy. Although we have here something more than a 'piecemeal analysis,' it does seem that we will have to wait for more uncertain years before we will see the promised great work on paper. It is probably this circumstantialism of Gripaldo that allows for his contextualization of Filipino philosophy. He is conscious of his coming from the signposts of his contemporaries, but also from those of the great Filipino personalities illustrated on the cover of his 2009 collection of essays, The Making of a Filipino Philosopher and Other Essays. His message is well-taken, but it remains anybody's guess whether the great work will or can be written after all. ${ }^{33}$

Florentino Timbreza is another Filipino philosopher who is trying hard to deserve the title while sourcing materials from all sorts of influences, Eastern and Western. Many of his works are also articulated in Tagalog, the main local language. He has this to say:

Hindi lamang ang mga dayuhan - ang mga Griyego, Amerikano, Intsik o Kastila ang may karanasan. Ang lahing

${ }^{49}$ Rolando M. Gripaldo, Circumstantialism (Dumaguete City: Silliman University Press, 1977).

\footnotetext{
${ }^{50} \mathrm{Ibid} ., 11$.

${ }^{51}$ Ibid., 112.

${ }^{52} \mathrm{Ibid}$.

${ }^{53}$ Editor's note: Gripaldo died in 2017.
}

(c) 2019 Romualdo E. Abulad https://www.kritike.org/journal/issue 25/abulad1 december2019.pdf ISSN 1908-7330 
Kayumanggi ay may natatanging karanasan din na singyaman at singdakila nga karanasan ng ibang mga lahi. Isa pa, kung ang pilosopiya ay nababatay sa mga pandaigdigang pananaw na angat sa tunay na karanasan sa buhay, pinatutunayan nito na mayroong pilosopiyang Pilipino, sapagkat mayroon din namang natatangi't katutubong pag-iisip at mga pandaigdigang pananaw ng mga Pilipino na batay sa likas nilang karanasan sa buhay. ${ }^{54}$

It is this attempt to draw a universal philosophy from the particular and specific experiences of the Filipinos which makes Timbreza a philosopher using the anthropological approach. To Gripaldo, this might be 'piecemeal' and, like in Mercado's case, the voluminous and thorough treatment of the subject has yet to see the light of day. What, in fact, Timbreza would like to do is as follows:

... sinikap na pinagsama-sama, pinag-ugnay-ugnay at
pinagtugma-tugma ang mga salawikain at mga kasabihan ng
mga mamamayang naninirahan sa mga pangunahing pookng
kapuluan: Tagalog, Ilokano, Ivatan, Pampanggao, Bisaya,
Tiruray, Tausug, Maranao, Maguindanao, Aklano,
Bukidnon, Subuanon, Zambaleno, Romblomanon, Kinaray-a,
Waray, Kalinga-Banao.55

Each chapter is supposed to do that on a particular area supposedly an element of the Filipino consciousness, the "diwang Pilipino." That's a tall order, and a short 148-page work cannot be expected to satisfy the ambitious goal, perhaps more appropriately for an anthropologist than for a philosopher.

Perhaps an even better work of Timbreza is the one produced by De La Salle University in 1999 before his retirement as a teacher there, appropriately titled Intelektwalisasyon ng Pilosopiyang Filipino. He minces no words about his expectation of ourselves as Filipino philosophers:

Dapat tayong mag-isip ng sarili nating pag-iisip at hindi ang pag-iisip ng iba. Tayo ay mamilosopiya ng sarili nating pilosopiya at hindi ang pilosopiya ng ibang lahi. Sinumang namimilosopiya sa pamamagitan ng pilosopiya ng ibang tao ay walang sariling pilosopiya. Sinumang nasisiyahan na mag-

${ }^{54}$ Florentino T. Timbreza, Pilosopiyang Pilipino (Manila: Rex Book Store, 1982), 2.

55 Ibid., 8.

(C) 2019 Romualdo E. Abulad https://www.kritike.org/journal/issue 25/abulad1 december2019.pdf

ISSN 1908-7330 


\section{PILOSOPIYANG PINOY}

isip sa pamamagitan ng pag-iisip ng iba ay salat sa sariling pag-iisip. ${ }^{56}$

This is what he calls his "challenge" (hamon) to his fellow philosophers.

Hanggang kailan tayo mananatiling bilanggo ng pag-iisip ng iba? Bakit hindi natin gamitin an gating sariling pag-iisip? Bakit pa tayo paaalipin sa pilosopiya ng ibang tao samantalang kaya naman nating mamilosopiya sa ating sarili mismo? Ito ang pangalawang hamon ng librong ito sa bawat Filipino na mayroong wagas na pagmamahal sa kanyang tunay na pagkatao. ${ }^{57}$

It is in response to this challenge that he proposes the "intellectualization of Filipino philosophy." This intellectualization process of Filipino philosophy goes through five phases: "(1) pagsasalin, (2) konseptwalisasyon, (3) interpretasyon o pagpapakahulugan, (4) paghahambing, at (5) repleksyon o pagmumuni." 58 For a philosopher who seems to be aiming at something purely indigenous, Timbreza is unabashedly coming from a translation and a re-conceptualization of the Chinese philosopher, Lao Tzu. He ends up comparing Lao Tzu's wise sayings with those of the Ilokano, Tagalog, Ilonggo, Cebuano, Tausug, Tiruray, Pampanggo, Boholano, Ivatan, Maguindanao and Maranao. ${ }^{59}$ For this purpose, his 230 pages cannot be said to be sufficiently long enough; it remains, in Gripaldo's vocabulary, 'piecemeal.'

The setback of the anthropological approach for a philosopher is the fact that it might as well have been undertaken by professional anthropologists themselves, not by philosophers. Claude Levi-Strauss is a case in point of a trained anthropologist who is so good at his craft that he inevitably finds his way back to its philosophical source. ${ }^{60}$ It is philosophy

${ }^{56}$ Florentino T. Timbreza, Intelektwalisasyon ng Pilosoiyang Filipino (Manila: De La Salle University Press, Inc., 1999), xi.

57 Ibid., xii.

58 Ibid., 3.

${ }^{59} \mathrm{Ibid} .$, e.g. 31-33, 46-48, and so on. Each chapter follows this methodology, which is really no different from the methodology used in Pilosopiyang Pilipino. The same criticism may be therefore be labeled on this new work.

${ }^{60}$ Claude Levi-Strauss's rigorous anthropological writings are saturated through and through with philosophic discipline, he writes: "But what confers upon kinship its socio-cultural character is not what it retains from nature, but, rather, the essential way in which it diverges from nature. A kinship system does not consist in the objective ties of descent or consanguinity between individuals. It exists only in human consciousness; it is an arbitrary system of representations, not the spontaneous development of a real situation." Structural Anthropology, trans. by Claire

(c) 2019 Romualdo E. Abulad

https://www.kritike.org/journal/issue 25/abulad1 december2019.pdf

ISSN 1908-7330

(c) BY-NC-ND 
that gives depth to his anthropology, but a philosophy which is not conscious of itself, conscious only of the fact that it is trying to break as profoundly as possible through the surface of kinship and other social relationships. This requires meticulous description of the phenomena under study, which is why Levi-Strauss' works can at times be technical and laborious, if not voluminous.

Perhaps the anthropological approach, called by Gripaldo the cultural approach, ${ }^{61}$ should better left to trained anthropologists. What a number of our Filipino philosophers are trying to do shows somewhat frustrated efforts to hurry into profound conclusions on the basis of random and rambling empirical data. The upside of it is that it becomes clear thereby that anthropology, like all the other sciences, hide philosophical underpinnings, without which a scientific or cultural insight rings hollow, if not shallow. Anthropology needs philosophy if it is to show any amount of rigorous discipline and insight. But all this should not be construed as meaning that philosophers can dabble in anthropology as well as anthropologists themselves. Yet, the combination is profound, but its masterpiece is yet to be written by a Filipino philosopher.

Perhaps the fate of some brilliant colleagues of ours in San Beda can teach us a lesson or two about the appropriate place of cultural and anthropological scholarship in the academic scheme of things. It might well be reasonable, after all, that such bright proponents as F.P.A. Demeterio and his group had to see the closure of their department and their eventual relocation in the area of Philippine Studies of the De La Salle University.

What seems to be the present state of affairs is not necessarily tantamount to the demise of the anthropological or cultural approach, whose first great work in philosophy we might not yet have seen. But, after all that has so far been said and done, it can certainly safely be said already that this is not the only way, perhaps not even the best way, of doing Filipino philosophy. Perhaps, I dare to say, it might not even be a wrong strategy to consciously do Filipino philosophy, but only as a way of reviewing what so far our Filipino philosophers have done and assessing whether there has been anything substantial that has already come out of their effort. Even this might not be too wise to undertake yet, since we are still too close to our writers to

Jacobson and Brooke Grundfest Schoepf (New York: Doubleday \& Company, Inc., 1967), 48-49, emphasis mine.

${ }^{61}$ Gripaldo, Making of a Filipino Philosopher, 1-8, also 41-42. At one point, Gripaldo minces no words and asserts that "When I speak of Filipino philosophy, I do not mean the approach used by Leonardo Mercado and Florentino Timbreza, which I call the 'cultural approach' or 'Filipino ethnophilosophy' in that they attempted to extract, as it were, the philosophical underpinnings or presuppositions of a people's culture as culled from their languages, folksongs, folk literature, folk sayings, and so on." The Making of a Filipino Philosopher, 63.

(C) 2019 Romualdo E. Abulad

https://www.kritike.org/journal/issue 25/abulad1 december2019.pdf

ISSN 1908-7330 


\section{PILOSOPIYANG PINOY}

be in a position to make an objective and accurate judgment of ourselves. I suggest that the best strategy is still not to indulge in any strategy at all, but simply to philosophize as one is inspired to do, without the thought that how one does it is the only way of doing Filipino philosophy. For, after all, as Quito would often say during her time, philosophy knows neither gender nor nationality, neither chronology nor religion. Her open-mindedness is legendary. Let me quote her here lengthily, for it seems to me that this philosopher, who was brightest light of her generation, can still be arguably considered as unsurpassed in many ways. In her "Homage to Jean-Paul Sartre," she has this to say:

My guideline in the study of philosophy has always been to render to every philosopher the widest possible benevolence of interpretation ... I have made openmindedness a sine qua non of philosophical research, and I contend, as a matter of creed, that there is no philosophical system that is completely wrong, hence to be summarily condemned, nor is there one that is completely right and therefore to be totally accepted. ${ }^{62}$

In "A New Concept of Philosophy," she is unambiguous: "Philosophy should have no color, no religious affiliation ... Philosophy should be a free science that seeks its own paths." 63 In writing "Three Women Philosophers," she aims "to prove that the mind has no sex or gender, and that sound thinking can originate from anyone, male or female." 64

Perhaps the best articulation of Quito's concept of philosophy is the one she gave as her inaugural address in the University of Sto. Tomas for the academic year 1967-68, part of which reads:

If I were to be asked to define philosophy, I must answer that I cannot. Philosophy is undefinable, i.e., it knows no limits just as the human mind knows no boundaries in its search for the rational explanation of reality and of man himself. No formula can ever exhaust the meaning of philosophy: all speculations about it have their own

${ }^{62}$ Emerita S. Quito, A Life of Philosophy: Festschrift in honor of Emerita S. Quito (Manila: De La Salle University Press, 1990), 622. This festschrift contains all the works of Quito and remains as the most monumental philosophical volume in the country. See also page 8 , where she contends that "there is no philosophical system that is completely wrong, hence to be summarily condemned, nor is there one that is completely right and therefore to be totally accepted."

${ }^{63}$ Ibid., 10.

${ }^{64}$ Ibid., 651.

(c) 2019 Romualdo E. Abulad

https://www.kritike.org/journal/issue 25/abulad1 december2019.pdf

ISSN 1908-7330

(c) BY-NC-ND 
value and truth. We can only delve into philosophy by actually experiencing it. The best we can manage, therefore, by way of an answer to the question of what is philosophy is to give a philosophizing one: Philosophy is a discipline where the questions are more important than the answers and every answer becomes a new question. ${ }^{65}$

This attitude of Quito is what explains her open-minded approach to philosophy. For her, philosophy "is necessarily a never ending quest" as well as "a private, personal one." 66 Thus, "answers cannot be formulated in articles of faith" and are "never meant to be dogmatic or catechetical," for they always "leave a margin for dissension and interpretation." 67 "Philosophy is not a closed science where questions have been answered for all time," Quito says, "It should not stop the work of successive generations but should rather encourage it by orienting itself towards the future." 68 She is of the opinion that "until we learn to assume an open attitude in regard to new philosophical doctrines, we have not yet arrived at philosophical maturity." 69

The fecundity of such a philosophical stance is shown by Quito's intellectual flexibility. In the "Introduction" to her Festschrift I took note of something which may be said to be in favor of her open and historically based approach. "It is, in a word, Filipino. Whereas Indians naturally show preference for Indian thought and Frenchmen for French thought, Filipinos are prone to adjust easily to varied, even contradictory, schools of philosophy."70 I traced this historically to the fact that, culturally speaking, unlike India or China (for example), we are a nation without solid tradition. "Is this a state of affairs that one should deplore? Sure enough, we might consider this predicament a weakness, but second thoughts could reveal it as a blessing and a strength. Of all peoples, we are in the best position to start anew from scratch, and in philosophy this could prove to be a fortune rather than a curse," 71 I said.

Socrates is the philosopher's philosopher mainly because he knows that he does not know. This learned ignorance was applied to all classical thought about two millennia later by René Descartes who smartly responded to the skeptical climate of his time with his unrelenting methodic universal

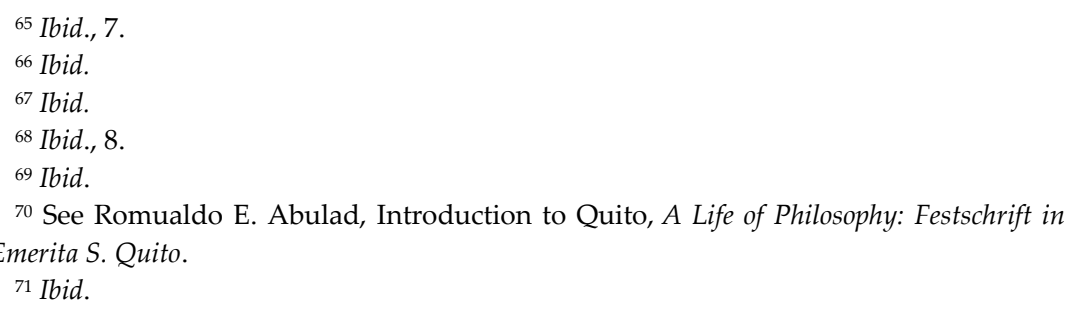




\section{PILOSOPIYANG PINOY}

doubt. This was consciously repeated two thousand years thereafter by Edmund Husserl who consciously preceded his phenomenology with the universal epoche, all in an attempt to establish that crucial beginning which would destine all succeeding knowledge as indubitably certain. Even that philosophy, certain though it might be, continues to bear traces of that presence which makes contemporary deconstruction possible. Postmodernism has at last found the key that would completely secure the foundationless and groundless knowledge whose unpredictable insights are boundless and limitless.

By his very nature, the Filipino is without roots. The anthropological effort, which provides one major task of contemporary philosophy in our country, must be pursued, but it remains true that, until now, the archaeological findings have been somewhat ridiculously magnified, revealing fossils that do not have ${ }^{72}$ too much substance yet. The worse about the anthropological approach is that it tends to arrogate unto itself the truth about the Filipino mind, thus excluding or at least debasing other so-called merely expository, descriptive, or non-anthropological philosophies. And these others are, so to speak, legion. Ateneo's legendary preoccupation with phenomenology and existentialism must have now produced a library that includes such bright academics as Roque Ferriols, Ramon Reyes, Leo Garcia, Manuel Dy, Tomas Rosario, Ranier Ibana, and Albert Alejo. The University of Sto. Tomas and De La Salle University have seen an overlap of prestige in the likes of Emerita S. Quito, Claro Ceniza, Alfredo Co, Paolo Bolaños, and Florentino Timbreza. And let's not demean our very own Cebuano institution, the University of San Carlos, which has been the home of the SVDs Leonardo Estioko, Quintin Terrenal, Florencio Lagura and Raymun Festin, as well as contemporary non-SVDs like Amosa Velez, Rosario Espina and Ryan Urbano. This list is far from complete and exhaustive, but only because I am not cognizant of what's going on everywhere, not even in the other academic institutions, such as UP and Silliman. However, the likes of the ones I've randomly mentioned would have to be excluded if the anthropological approach would be declared as the sole legitimate method for the creation of a Filipino philosophy. I would not go for such a proposition; I'd prefer Quito's prescription of open-mindedness.

It is with much ease that we understand the spirit of postmodernity precisely because of our lack of rootedness, or perhaps more accurately the meagerness of our roots. There is nothing to be ashamed of in the historical fact that we do not have a tradition as immensely rich as, say, China and India. We are not China or India, nor Greece or Rome, nor Germany or France,

72 Editor's note: In the original manuscript, the author wrote, "with not" which we have replaced here with "do not have" for clarity.

(c) 2019 Romualdo E. Abulad

https://www.kritike.org/journal/issue 25/abulad1 december2019.pdf

ISSN 1908-7330

(cc) BY-NC-ND 
nor England or Australia. We are not Africa, nor are we Spain or America. This is the Philippines and all the facts about the Philippines belong to me, even the fact of my own lack - the lack of a long history and a glorious cultural heritage. The mistake is to dwell on this lack and do nothing about it; that would make us either plain stupid or lazy, which we are not supposed to be. The cue comes from the existentialist Jean-Paul Sartre, when he says: "Existence precedes essence," he means that, "man first of all exists, encounters himself, surges up in the world - and defines himself afterwards."73 The moment's task assigned to a Filipino philosopher is one of existential definition. If you don't believe that there is such a thing as a Filipino philosophy, then one thing I may ask you to do is gather all the writings of the authors I have just named above, see for yourself how much work has already been done, quantitatively, and then assess the intellectual worth of its entirety, qualitatively.

You are asking, "Uso pa ba ang Pilosopiyang Pinoy?" I say, with all my due respect to you, that the question is missing the point. Philosophy is not at all about fads and fashions. In recent years, philosophy majors have dramatically decreased in number. Just in June of this year, we saw our undergraduates decline from about a hundred to just about seventy, which is due to the closure or transfer of some of the formation houses in Cebu. One or two congregations ceased sending their boys to us and instead have sent them to the Rogationist Seminary, which we don't consider a bad thing at all. Not a few of the formators in that seminary have been formed by us in the University of San Carlos, and it's not a bad idea if they start using their learned expertise to expand the possibilities for seminaries in the region. The implication of this phenomenon for us in the University is simply that we now have to re-design our concept of philosophy in a way that will cater primarily to non-seminarians. Again, not a bad idea. Philosophy is not meant only to prepare students for either the priesthood or the legal profession. More and more, the relevance of philosophy is being recognized as foundational for all disciplines, sacred or profane. The first department to connect with us this academic year is the Biology Department, seeking to evolve together with a course in Bioethics, both for their graduate and undergraduate majors. Just a month ago, before the start of the current semester, the Physics Department sent me an email asking us to meet with their teachers in an effort to understand some rudiments of Philosophy of Science. In January next the second batch of Chinese students from the Mainland will arrive in our school to pursue a Ph.D. in Business Management, and the College of Business and Entrepreneurship (which is

73 Jean-Paul Sartre, Existentialism and Humanism, trans. by Philip Mairet (London: Methuen, 1948), 28.

(C) 2019 Romualdo E. Abulad

https://www.kritike.org/journal/issue 25/abulad1 december2019.pdf

ISSN 1908-7330

(cc) BY-NC-ND 


\section{PILOSOPIYANG PINOY}

how they would like to call themselves in the future) has asked the Philosophy Department to offer the first two modular classes, specifically instructing us to do Philosophy of Man and Philosophy of Culture. Trends like this are bound to set the trend for the re-designing of philosophy courses in our time.

I shall tell you something more which, at first, will be hard for many people to understand. We have decided in the University of San Carlos to fuse the two Departments of Philosophy and Religious Education; now we have just one Department of Philosophy and Religious Studies. The idea of the merger is not new; it has been floating for many years, but habits, as they say, die hard. We continue to be the premier university in these parts in so far as philosophy is concerned, since we remain to be the only school here which has a complete program of philosophy from the undergraduate to the Ph.D. and we have enough of our share of doctors in the faculty. Why, then, fuse with another department?

More than half of a century ago, in May 1959, an academic named Charles P. Snow delivered an otherwise insignificant lecture in the halls of Cambridge. Snow described what happened next in a 'second look' of it he made in 1963:

According to precedent, the lecture was published, as a paper-covered pamphlet, the day after it was delivered. It received some editorial attention but, in the first month, not many reviews. There was not, and could not be, any advertising. Encounter published long extracts, and these drew some comment. I had a number of interesting private letters. That, I thought, was the end of it. ${ }^{74}$

It did not turn out to be that way at all. "By the end of the first year I began to feel uncontrollably like the sorcerer's apprentice. Articles, references, letters, blame, praise, were floating in-often from countries where I was otherwise unknown ... The literature has gone on accumulating at an accelerating pace." 75 Today, who has not heard of C.P. Snow's critique of the 'two cultures'? "I intend something serious," he said,

I believe the intellectual life of the whole of western society is increasingly being split into two polar groups ... Literary intellectuals at one pole - at the other

\footnotetext{
74 C.P. Snow, "The Two Cultures: A Second Look (1963)," in The Two Cultures (Cambridge: Cambridge University Press, 1998), 53.

${ }^{75}$ Ibid., 54.

(c) 2019 Romualdo E. Abulad

https://www.kritike.org/journal/issue 25/abulad1 december2019.pdf

ISSN 1908-7330
}

(c) $)$ BY-NC-ND 
scientists, and as the most representative, the physical scientists. Between the two a gulf of mutual incomprehension-sometimes (particularly among the young) hostility and dislike, but most of all lack of understanding. ${ }^{76}$

What follows is, as they say, history. The attempts to bridge cultures through inter- and multi-disciplinarity is well known. Borders have cracked and walls have crumbled, and the new time begins to call for the fusion of horizons. Hegel once said of an idea whose time has come, that one cannot arrest it no matter what obstacles stand in the way.

For the rest it is not difficult to see that our epoch is a birth-time, and a period of transition. The spirit of man has broken with the old order of things hitherto prevailing, and with the old ways of thinking, and is in the mind to let them all sink into the depths of the past and to set about its own transformation. ${ }^{77}$

While the collapse of borders and the merger of horizons are taking place, the two cultures proceed in a direction where the scientific edge seems to be reducing the humanistic disciplines to an endangered species. Everybody is seeking to quantify itself, measuring its capacity to be a science in terms of mathematics and calculation. Formulas and statistics are taking the place of purely descriptive studies, so that even what belongs to the human side of things is now being forced to follow the mold of quantification. Psychology now belongs to the social sciences, which continue to ape the methods of mathematics and physics. The mechanization of knowledge gives rise to an amazing world of science and technology, a blessing no doubt that owes itself to the genius of man, but a curse too that is putting the humanities or liberal arts, what the Germans call Geisteswissenchaften, on the sidelines.

Even philosophy, as well as to some extent theology, has important proponents which are seriously pondering on aligning the spiritual disciplines to science and measurement. Allow me to say that much of what I have referred to as the anthropological approach to philosophy tends to lean on this direction. This causes a deep divide between the two disciplines, the naturalistic and the humanistic disciplines (Naturwissenschaften and Geisteswissenschaften). Much of the latter has moved over to the empirical and scientific side of the academe, so that what we now call the social sciences are

\footnotetext{
${ }^{76}$ Snow, “The Rede Lecture (1959)," in The Two Cultures, 3.

${ }^{77}$ Hegel, Phenomenology of Mind, 75.
}

(C) 2019 Romualdo E. Abulad https://www.kritike.org/journal/issue 25/abulad1 december2019.pdf 


\section{PILOSOPIYANG PINOY}

no longer really within the sphere of the liberal or spiritual disciplines. In the University of San Carlos, in particular, only philosophy and religion remain as the bulwark of the humanities. Literature belongs to the Department of Languages and Literature which is currently slight in literature and large in linguistics, whereas linguistics is either grammar or a social science, thus more akin to science than to the arts. The arts, on the other hand, are in the hands not of the College of Arts and Sciences but of the College of Architecture and Fine Arts, a competent and highly entrenched department which is unwilling to get itself subjugated together with philosophy and religion under the Humanities cluster. That leaves philosophy and religion the only remaining stronghold of the spiritual sciences (Geisteswissenschaften), which is the rationale for their having to work together and join hands especially in the widespread mission of Ethics and Catholicity. This, Ethics and Catholicity, is being strongly brought forward by the current leadership of my University, and philosophy is certainly a major partner in this mission or what we SVDs call prophetic dialogue.

Moreover, the government's Philippine Main Education Highway $(\mathrm{PMEH})$ is now on the verge of implementation on account of global moves to discredit nations with less than twelve years of basic education. There seems to be no more doubt that two more years will be added before one can go to college, after which a young candidate has the option to proceed either to the academic university or to the vocational technical school. This move will professionalize the college offerings and, in all likelihood, the current practice of two years of general liberal education in college will go down to the level of senior high school. There will be a lot of rethinking in higher education and my suspicion is that our radical decision to collapse philosophy and religious studies into one department will prove to be a felicitous move that will facilitate the road for the other disciplines.

What all this amounts to is the futility of an exercise that fears for the life of philosophy as a professional discipline in the future. One thing that we should perhaps always keep in mind is that the death of philosophy is most ably undertaken by no less than the ablest philosophers themselves, think only of Socrates, Thomas Aquinas, Francis Bacon, René Descartes, the empiricists John Locke, George Berkeley and David Hume, Immanuel Kant, Friedrich Nietzsche, Edmund Husserl, Martin Heidegger, Ludwig Wittgenstein and the deconstructionists like Jacques Derrida and Jean Baudrilliard. No other discipline faces its own fragility and possible mortality more frontally than philosophy itself. There is no need to fear that we shall not be relevant. If we ever become irrelevant, it's no thanks to ourselves who might not have been willing to do as expected of philosophers: lead the pack to new spiritual frontiers coming from the uncertainties and challenges of the present times.

(c) 2019 Romualdo E. Abulad

https://www.kritike.org/journal/issue 25/abulad1 december2019.pdf

ISSN 1908-7330

(c) $)$ BY-NC-ND 
Philosophy continues to be the handmaid of religion, but not in so far as it is being asked to assist in a formulaic and mechanical imitation of, say, the Summa Theologiae of St. Thomas Aquinas. If it were only this, then religion would have need not so much for philosophy as for an intellect keen enough to literally commit to memory scholastic manuals for exact delivery at baccalaureate exams. The importance of philosophy as a tool or organon is, in fact, not limited to theological subjects but extends to all thinking in general, which means to all disciplines. This is why all academic courses will be impoverished, both formally and substantially, when not steeped in the discipline of philosophy. In other words, all areas of knowledge and behavior need philosophy as a fundamental discipline, without which they will lack in either rigor or depth and will eventually wilt and collapse. Beyond all this dirty work philosophy is asked to do on behalf of the existing sciences, it also stands as a pure discipline on its own footing. What Kant, Heidegger and Wittgenstein have accomplished could not have been done outside of pure philosophy, whose speculative and practical results have brought about the culture of postmodernity.

Filipino philosophy can extricate itself from global philosophy only at its own expense. The Philippine Main Education Highway has been conceived precisely in response to global requirements, thanks to international accords like APEC, Washington and Bologna. Any isolationist move on the part of Filipino philosophers will be destructive for its own mission in an age and time which calls for linkages and encompassing solutions. It is philosophy, one might say, which has brought the world to its postmodern situation, and it is philosophy's continuing task to guide humanity in the direction where the spirit leads it. In all this, there is a partnership between philosophy and religion which we should not try to frustrate. The secular Spirit is basically only the other side of the mystical Spirit, in the same way that Spinoza's natura naturans and natura naturata are identical.

Department of Philosophy, University of Santo Tomas, Philippines Loyola School of Theology, Ateneo de Manila University, Philippines

Divine Word Mission Seminary (Christ the King Mission Seminary), Philippines

\section{References}

Abulad, Romualdo E., Introduction to Emerita S. Quito, A Life of Philosophy: Festschrift in honor of Emerita S. Quito (Manila: De La Salle University Press, 1990).

Abulad, Romualdo E./Department of Philosophy, De La Salle University, Readings in Filipino Philosophy (Manila: De La Salle University, 1990).

(C) 2019 Romualdo E. Abulad

https://www.kritike.org/journal/issue 25/abulad1 december2019.pdf

ISSN 1908-7330

(cc) BY-NC-ND 


\section{PILOSOPIYANG PINOY}

Alejo, Albert E., Tao pô! Tuloy! Isang Landas ng Pag-unawa sa Loob ng Tao (Quezon City: Ateneo de Manila University Office of Research and Publications, 1990).

Aristotle, De Anima, trans. J.A. Smith, in The Basic Works of Aristotle, ed. by Richard McKeon (New York: Random House, 1941).

Confucius, The Analects, trans. by Wing-tsit Chan, in A Source Book in Chinese Philosophy (Princeton, New Jersey: Princeton University Press).

Derrida, Jacques, Margins of Philosophy, trans. by Alan Blass (Brighton, Sussex: The Harvester Press, 1982).

Gripaldo, Rolando, Circumstantialism (Dumaguete City: Silliman University Press, 1977).

The Making of a Filipino Philosopher and Other Essays (Mandaluyong City: National Book Store, 2009).

Hegel, G.W.F., Phenomenology of Mind, trans. by J.B. Baillie (New York: Harper \& Row, 1967).

Levi-Strauss, Claude, Structural Anthropology, trans. by Claire Jacobson and Brooke Grundfest Schoepf (New York: Doubleday \& Company, Inc., 1967).

Lyotard, Jean-Francoiş, The Postmodern Condition: A Report on Knowledge, trans. by Beoff Bennington and Brian Massumi (Minneapolis: University of Minnesota Press, 1993).

Mercado, Leonardo N., Elements of Filipino Philosophy (Tacloban City: Divine Word University Publications, 1993).

Explorations in Filipino Philosophy (Manila: Logos Publications, 2009).

The Filipino Mind: Philippine Philosophical Studies II (Manila: The Council for Research in Values and Philosophy and Divine Word Publications, 1994).

Miranda, Dionisio M., Buting Pinoy: Probe Essays on Value as Filipino (Manila: Divine Word Publications, 1992).

Plato, Phaedrus, trans. by R. Hackforth, in Plato: The Collected Dialogues, ed. by Edith Hamilton and Huntington Cairns (New Jersey: Princeton University Press, 1973).

Quito, Emerita S., A Life of Philosophy: Festschrift in honor of Emerita S. Quito (Manila: De La Salle University Press, 1990).

Sartre, Jean-Paul, Existentialism and Humanism, trans. by Philip Mairet (London: Methuen, 1948).

Snow, C.P., The Two Cultures (Cambridge: Cambridge University Press, 1998). Timbreza, Florentino T., Intelektwalisasyon ng Pilosoiyang Filipino (Manila: De La Salle University Press, Inc., 1999). Pilosopiyang Pilipino (Manila: Rex Book Store, 1982).

(C) 2019 Romualdo E. Abulad https://www.kritike.org/journal/issue 25/abulad1 december2019.pdf ISSN 1908-7330

(cc) BY-NC-ND 